\title{
PERUBAHAN ORIENTASI MATA PENCAHARIAN PENGRAJIN LOGAM DESA CIBATU KECAMATAN CISAAT KABUPATEN SUKABUMI
}

\author{
Farhan Firdaus ${ }^{1}$, Gurniwan Kamil Pasya ${ }^{2}$, Syaifullah Syam ${ }^{3}$ \\ ${ }^{1}$ SMA Negeri 1 Cibadak \\ 2Dosen Program Studi Pendidikan Sosiologi \\ ${ }^{3}$ Dosen Program Studi Pendidikan Sosiologi
}

\begin{abstract}
ABSTRAK
Penelitian ini bertujuan untuk mengetahui kondisi pengrajin logam, faktor yang mempengaruhi perubahan orientasi serta upaya yang dilakukan mantan pengarjin logam untuk memenuhi kebutuhan hidup. Penelitian menggunakan pendekatan kualitatif dengan metode studi kasus. Hasil penelitian menunjukkan adanya perubahan orientasi mata pencaharian masyarakat Desa Cibatu Kecamatan Cisaat terutama pada mata pencaharian pengrajin logam. Upaya yang dilakukan mantan pengrajin logam untuk memenuhi kebutuhan hidup dengan menekuni mata pencaharian baru yang merupakan langkah nyata dari pemenuhan tanggung jawab. Alasan perubahan orientasi mata pencaharian disebabkan faktor sosial, ekonomi dan teknologi.
\end{abstract}

Kata kunci : mata pencaharian, pengrajin logam, industri kecil

\section{PENDAHULUAN}

Corak masyarakat Kabupaten Sukabumi khususnya Desa Cibatu Kecamatan Cisaat bermata pencaharian sebagai pengrajin logam. Desa Cibatu Kecamatan Cisaat memiliki sejarah sebagai ikon kerajinan logam di kabupaten Sukabumi. Salah satu industri sekunder di pedesaan yakni industri kerajinan logam yang mencakup penempaan besi (yang biasa disebut pandai besi), penuangan besi, penuangan tembaga dan campurannya, kerajinan perak dan emas, industri baru yang memproduksi barang dengan mengelas tabung dan lempeng logam buatan pabrik, biasanya alumunium atau seng, industri perbaikan barang-barang, termasuk patri yang memperbaiki barang-barang dari logam. Produk yang dihasilkan seperti peralatan rumah tangga, pertanian, industri seperti pembuatan pisau, arit, cangkul dan sejenisnya. Dunham (2008:37) menjelaskan mengenai industri pendukung sektor ekonomi bahwa,

kehadiran industri pandai besi sebagai industri kecil di pedesaan dapat menciptakan lapangan pekerjaan yang luas dengan penghasilan memadai untuk masyarakat sekitarnya dan juga sebagai industri pendukung pertumbuhan sektor ekonomi yaitu pertanian.

Profil industri logam Desa Cibatu Kecamatan Cisaat Kabupaten Sukabumi masih bersifat tradisional 
terdapat di rumah-rumah (home industry) dan termasuk industri kecil.

\section{ORIENTASI MATA PENCAHARIAN PENGRAJIN LOGAM SAAT INI}

Industri rumahan pandai besi beserta masyarakatnya merupakan warisan turun temurun dari sejak dulu. Generasi muda telah menyadari akan arti ekonomis warisan tersebut. Tidak banyak di antara mereka melanjutkan sekolah ke tingkat lanjutan hanya sebatas sekolah dasar saja. Setelah itu lapangan kerja warisan nenek moyang dapat menyerap anak-anak tersebut untuk bekerja, walaupun dengan mengalami pasang surut. Dunia pandai besi belum bisa menjamin ketersediaan lapangan kerja yang tetap dengan tingkat pendapatan yang tetap pula.

Mayoritas penduduk Desa Cibatu bekerja mengandalkan pandai besi sebagai mata pencaharian utama, membuka usaha sendiri dengan menerima order (pesanan) dari pemesan memalui tengkulak. Sistem kerja seperti ini mereka sebut dengan gaweun (pekerjaan yang dilakukan borongan sesuai dengan jangka waktu proses produksi). Adapun sistem gaweun ini, pandai besi terlebih dahulu menerima pesanan dari tengkulak seperti pesanan golok, pedang, pisau dapur dan lain sebagainya. Proses produksi tersebut dikerjakan di gosali (bengkel) mereka masing-masing.

Setiap pandai besi memiliki keahlian masing-masing sesuai dengan keahlian dan kebutuhan. Proses produksi terdiri dari beberapa tahapan, antara lain produksi, seperti proses pemotongan logam, pembakaran logam, penempaan logam, ngagerinda, ngambil waja (baja), ngagagangan, panyipuhan. Sampai tahapan akhir yaitu proses pemasaran.

Setiap pandai besi mengerjakan tahap produksi sesuai dengan keahliannya, setiap tahapan pekerjaan yang sudah selesai segera dikirimkan ke pemesan melalui tengkulak atau langsung ke pemesan. Pandai lain yang memiliki keahlian seperti ini terdiri dari berbagai orang yang memiliki keahlian yang berbeda. Pandai besi mengirimkan kepada pandai besi lain untuk proses selanjutnya seperti tahapan ngagagangan (tahapan digunakan untuk memberi gagang pada peralatan) yang dilakukan diluar gosali (bengkel produksi) sehingga proses produksi terdiri dari berbagai tahapan dan berbagai pandai besi.

Perubahan orientasi mata pencaharian pengrajin logam merupakan perubahan yang tidak dikehendaki (unintended-change) atau perubahan yang tidak direncanakan (unplanned change) hal tersebut dikarenakan perubahan orientasi pengrajin logam tidak dikehendaki atau tidak direncanakan oleh masyarakat sendiri. Perubahan orientasi mata pencaharian pengrajin logam tidak direncanakan secara sistematis namun karena terdesak keadaan yang menjadikan perubahan orientasi mata pencaharian tersebut terjadi. Proses produksi yang semakin menurun menjadikan pendapatan semakin berkurang sedangkan 
kebutuhan untuk menutupi kekurangan tersebut merupakan hal yang dilakukan untuk memenuhi kebutuhan hidupnya. Perubahan dari aspek sosial merupakan suatu proses yang terjadi dalam masyarakat meliputi, aspek kehidupan sosial, interaksi sosial, status sosial dan tindakan sosial lainnya. Perubahan kendatinya terjadi karena adanya perubahan sikap dan perasaan bahwa ingin merubah struktur yang ada menjadi lebih baik lagi. Orientasi mata pencaharian ini diawali karena adanya perubahan yang terjadi terhadap kebutuhan. Hal ini menyebabkan pandai besi mengalami penurunan populasi, perubahan tidak berjalan secara tibatiba namun mempunyai gejala atau tahapan-tahapan sebelum mengalami perubahan.

FAKTOR-FAKTOR

YANG

MEMPENGARUHI

PERUBAHAN

ORIENTASI MATA PENCAHARIAN PENGRAJIN LOGAM DESA CIBATU KECAMATAN CISAAT KABUPATEN SUKABUMI

\section{a. Faktor sosial}

Hubungan yang terjalin antara majikan dan buruh pandai yang terjalin menyangkut persahabatan, pekerjaan serta hubungan kekeluargaan yang menjadikan faktor sosial yang mempengaruhi perubahan orientasi mata pencaharian pandai besi dan pengrajin logam. Seorang majikan dengan status sosial ekonomi yang lebih tinggi (majikan) menggunakan pengaruh dan sumber-sumber yang dimilikinya untuk menggunakan pengaruh dan sumber-sumber yang dimilikinya untuk memberikan perlindungan dan keuntungan bagi seseorang yang statusnya lebih rendah (buruh) dan sebaliknya membalas dengan memberikan dukungan dan bantuan secara umum termasuk pelayanan pribadi kepada majikan.

\section{b. Faktor ekonomi}

Faktor yang mempengaruhi penurunan hasil produksi, sebenarnya pesanan masih ada sampai saat ini namun terkendala modal dan memang harga produksi tidak sesuai dengan harga jual, lebih besar hagra produksi dibanding harga jual. Tidak ada sedikitpun keuntungan dalam memproduksi pesanan, jika dipaksakan proses produksi bisa berjalan namun kualitas barang yang menggunakan kualitas yang lebih rendah. Pandai besi juga pengrajin logam tidak mau memproduksi pesanan dengan kualitas yang berbeda karena akan merusak citra dan nama baik pandai besi dan pengrajin logam itu sendiri.

\section{c. Faktor teknologi}

Mata pencaharian pandai besi dari tahun ke tahun semakin menurun seiring berkembangnya teknologi permesinan yang menunjang kegiatan produksi, pekerjaan sebagai pandai besi dipilih untuk menghidupi keluarga dari pada kebutuhan keluarga tidak terpenuhi maka mata pencaharian pandai besi menjadi satu-satunya jalan untuk memenuhi kebutuhan hidup. Berbekal pengalaman yang didapatkan ketika menjadi buruh pandai besi, kemudian bekerja menjadi karyawan di CV.Alpindo sampai membuka bengkel sendiri untuk memproduksi kerajinan logam. Hal tersebut yang bisa dilakukan untuk memenuhi kebutuhan hidup keluarga. 
Peralatan produksi kini juga telah mengalami perubahan. Emposan (alat untuk menghembuskan api dengan bantuan tenaga manusia) merupakan peralatan yang sudah tidak ada lagi di tempat penelitian, pertimbangan mereka adalah tingkat panas dari besi tempa kurang tinggi.

Blower (alat untuk menhembuskan tenaga angin dibantu dengan tenaga listrik yang menggantikan fungsi emposan) Blower inilah yang menggantikan emposan (alat untuk menghembuskan api dengan bantuan tenaga manusia) karena dinilai sudah kirang efektif dan tidak banyak memakan tenaga manusia.

Keberadaan industri logam terbagi menjadi dua kategori fase yaitu keberadaan pandai besi mulai muncul dan berkembang dari zaman penjajahan Belanda sampai pertengahan tahun 1990-an, sedangkan keberadaan pengrajin logam muncul pada pertengahan tahun 1970-an beriringan. Seiring bertambahnya pesanan maka koperasi karya logam membentuk workshop (bengkel kerja) sebagai pelopor keberadaan industri pengrajin logam.

\section{UPAYA YANG DILAKUKAN MANTAN PENGRAJIN LOGAM UNTUK MEMENUHI KEBUTUHAN HIDUP}

1. Buruh diajak bekerja karena melihat saudara atau tetangga tidak bekerja.

2. Upaya mendapat modal utama yang digunakan berasal dari tabungan dan simpanan keluarga pandai yang diwariskan kepada generasi berkutnya.
3. Pemenuhan kekurangan modal dengan meminjam uang ke koperasi karya pusaka, sejak tahun 1972 dibentuk koperasi Karya Pusaka untuk mewadahi seluruh pandai besi dan pengrajin logam di Desa Cibatu.

4. Menekuni mata pencaharian baru yaitu:
a. Pengurus Koperasi BMT AL- Anhar
b. Penarik ojeg - calo
c. Petani Pemilik - Pedagang Warung
d. Petani pemilik- tukang pijat
e. Peternak Ikan Air Tawar - Tukang Kiridit
f. Petani Penggarap - Tukang Pijat
g. Buruh
h. Pedagang warung

\section{PENUTUP}

Hasil penelitian menunjukkan bahwa terdapat perubahan orientasi mata pencaharian pengrajin logam dan pandai besi Desa Cibatu Kecamatan Cisaat Kabupaten Sukabumi yang bertumpu pada sektor pertanian dan peternakan serta perdagangan dan jasa. Hal ini berdasarkan pada pertimbangan untuk lebih meningkatkan kesejahteraan hidup.

Terdapat tiga faktor signifikan
yang mempengaruhi perubahan
orientasi mata pencaharian yaitu (1)
sosial, (2) ekonomi dan (3) teknologi.
Upaya yang dilakukan mantan
pengrajin logam untuk memenuhi
kebutuhan hidup dengan menekuni
mata pencaharian baru yang
merupakan langkah nyata dari
pemenuhan tanggung jawab. Berbagai


mata pencaharian baru ditekuni mantan pandai besi dan pengrajin logam. Melalui pengalaman yang dimiliki sebelumnya serta belajar informal dari lembaga pelatihan kerja.

\section{DAFTAR RUJUKAN}

Adiatama, I dan Marfirani, R (2012) Pergeseran Mata Pencaharian Nelayan Tangkap Menjadi Nelayan Apung Di Desa Batu Belubang. Jurnal Prosiding Seminar Nasional Pengelolaan Sumberdaya Alam dan Lingkungan, hlm.105-114.

Dunham, S. (2008). Pendekarpendekar Besi Nusantara : Kajian Antropologi Tentang Pandai Besi di Indonesia. Bandung : Mizan 